\title{
高アルカリ塩化物環境下における炭素鋼の脆化割れに及ぼす
} ひずみ速度と水素発生電流の影響*

\author{
小林正人**, 西方 篤**, 水流徹** \\ ** 東京工業大学 大学院理工学研究科 材料工学専攻
}

\section{Effect of Stain Rate and Hydrogen Charging Current on Hydrogen Embrittlement of Carbon Steel in High Alkaline Chloride Environment*}

\author{
Masato Kobayashi**, Atsushi Nishikata** and Tooru Tsuru** \\ ** Department of Metallurgy and Ceramics Science, Graduate School of Science and Engineering \\ Tokyo Institute of Technology
}

\begin{abstract}
Hydrogen embrittlement of mild steel was examined by a slow strain rate test (SSRT) in a solution simulated the concrete with alkaline silica reaction (ASR), and the effects of strain rate and hydrogen evolution reaction current on the fracture strain were investigated. A reduction of the fracture strain was observed when the strain rate was small enough with some extent of hydrogen evolution current. Quasi-cleavage fracture surfaces were observed under hydrogen charging conditions, suggesting hydrogen embrittlement. The entry of hydrogen was effective only when the specimen deformed with necking. On the other hand, the amounts of hydrogen entering in the elastic and the plastic deformation regions before the maximum stress had very little effect against the reduction of fracture strain.
\end{abstract}

Keywords : alkaline silica reaction (ASR), rebar fracture, hydrogen embrittlement, slow strain rate test (SSRT), plastic deformation, necking

1. 緒

言

経済成長の鈍化，省資源・省エネルギーの推進，地球 環境への配慮などから社会資本の長寿命化, 劣化の定量 的な評価, 劣化防止と補修技術の確立に対する社会的な 要請が強まっている.

鉄筋コンクリートは鉄筋とコンクリートからなる複合 材料であり，任意の形状の構造物を経済的に造ることが 可能なことから, ダム, 橋梁, 海洋構造物と広範囲にわ たって使用されている．鉄筋はコンクリート内部の高ア ルカリ環境下で不働態化している．鉄筋コンクリートの 劣化は酸素, 二酸化炭素, 塩化物, 水などの腐食因子が コンクリート中を徐々に拡散して鋼材の腐食を引き起こ す外的要因に因るものと, アルカリ骨材反応 (Alkaline Silica Reaction, ASR) のようにコンクリートそのものの劣 化がある. ASRのメカニズムはセメント原料や骨材に由 来するセメント中の細孔溶液に存在する $\mathrm{Na}^{+}$や $\mathrm{K}^{+}$など のアルカリ金属イオンが骨材中に含まれる準安定なシリ カと反応するものである11. 反応生成物であるアルカリ シリカゲルが吸水することで膨張しコンクリートを内部 から劣化させるものである。この反応は膨張が非常にゆ っくりと長期間にわたって進行するという特徵がある. 佐藤ら ${ }^{2)}$ はASRによる膨張によって生じるコンクリート 供試体のひずみを計測しているが，このひずみから鉄筋 に発生する応力を計算により求めると, 降伏応力を超え

* 第 52 回 材料と環境討論会 (札幌, 2005 年), 材料と環境 2006 (つ くば, 2006 年) で発表

** $=152-8552$ 東京都目黒区大岡山 2-12-1 (2-12-1, O-okayama, Meguro-ku, Tokyo, 152-8552 Japan)
て引張強度に近い值になっていた。

近年の調査により ASR 損傷橋梁内部の鉄筋破断が報告 された ${ }^{3)}$, 4). 鉄筋破断事例はこれまでに約 30 例程報告さ れ5)，すべての事例に共通して主筋屈曲部，スターラッ プや帯鉄筋の曲げ加工部に破断が集中しているのが特徴

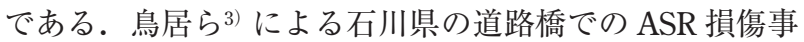
例の詳細な調査では, 損傷鉄筋に顕著な腐食は見られず 破断は断面欠損によるものではないこと, 破断部位には 絞り変形が認められず脆性的に破断したとされている。 また鉄筋破断は機械的な要因によるものであり，そのメ カニズムを以下のように述べている．施工時の鉄筋曲げ 加工によって屈曲部内側が強加工され著しく硬化する. スプリングバックにより異型鉄筋内側のリブ部の応力集 中部にクラックが発生する (一次亀裂)。このクラックが ASR によるコンクリートの膨張によって外側に向かって 進展し, 脆性的な破断に至る. さらに破断面の走查型電 子顕微鏡 (Scanning Electron Microscope, SEM) 観察によ って理解されたクラック進展方向に対する破断面の特徴 として ${ }^{6)}$, 一次亀裂は局所的なすべり変形による延性破 面であるが，その後の破面は脆性破壊であるへき開破面 を呈していることが認められた。この脆性破面の生成メ カニズムは曲げ加工による加工硬化と $\mathrm{C}, \mathrm{N}$ などの固溶 元素によるひずみ時効が与える破壊勒性值の低下による ものと推察している.

脆性的な破面が生じる要因としてほかには粗大な結晶 粒, 高速変形, 水素による脆化などが挙げられる. 損傷 鉄筋の調查 ${ }^{7}$ により実使用品は SD295A (JIS-G3112) 相 当であることから, その結晶粒が脆性的な破壊をするほ ど粗大ではない。また ASR の膨張速度は非常に遅いもの であるから高速変形によって生じたとは考えにくい. 佐々木ら ${ }^{8)}$ は曲げ加工部の加工硬化を考慮し加工履歴の 
異なる 4 種類の鉄筋試料を用いて, $\mathrm{pH}=2.0$ の硫酸溶液 中で $24 \mathrm{~h}$ 水素チャージをした試料を昇温脱離ガス分析 し, 強加工材で拡散性水素の放出ピークの増加を確認し ている.すなわち曲げ加工により水素脆化に影響を与え る拡散性水素の吸収量が増加し, 鉄筋の水素脆化感受性 が高まることを示した．強度が $1 \mathrm{GPa}$ を超えるような高 強度鋼では, $0.1 \mathrm{ppm}$ 程度の拡散性水素の吸収によって 水素脆化である遅れ破壊を起こし得ることが知られてお り, 加工硬化により水素脆化感受性が高まっている部位 は，鉄筋のような軟鋼であっても十分に遅れ破壊の危険 域に入っている可能性がある9 .

コンクリートの ASR 現象は数年を単位としてコンクリ ートが膨張するものであり，鉄筋にかかる荷重およびひ ずみは時間とともに変化する。年故, 鋼材が変形し続 けている動的状態での脆化を考慮する必要がある。一方, 通常のコンクリート中の細孔溶液はセメントの主成分で ある $\mathrm{Ca}(\mathrm{OH})_{2}$ の飽和溶液であり，その $\mathrm{pH}$ が $12 \sim 12.5$ の強アルカリ環境であることは知られており, 鉄筋は一 般に不働態化している. しかしながら ASR を起こす塩化 物含有の高アルカリ環境では不働態化せず水素発生電位 近傍の腐食電位を示す場合もあり ${ }^{10)}$, 水素による脆化が 生じることも考えられる。

そこで本研究ではコンクリート環境を模擬した高アル カリ塩化物環境下での鋼材の水素脆化を実験的に模擬す ることを目的とする．模擬環境下で鋼材にカソード分極 によって水素をチャージしながら引張試験を行い, 脆化 割れに及ぼすひずみ速度と水素侵入速度の影響を明らか にし，鉄筋破断における水素脆化の可能性を検討する.

\section{2. 実}

験

\section{1 供 試 材}

供試材は鉄筋コンクリート用異型棒鋼 SD345（JISG3112）で，JIS に規定された成分量は C $\leqq 0.27$ mass\%， $\mathrm{Si} \leqq 0.55$ mass \% $\mathrm{Mn} \leqq 1.60$ mass $\%, \mathrm{P} \leqq 0.040$ mass\%, $\mathrm{S} \leqq 0.040$ mass\%である. 直径 $13 \mathrm{~mm}$ の鋼材から Fig. 1 に示す形状の試験片を切削加工により作製した．標点距 離は $25 \mathrm{~mm}$, 平行部直径は $4 \mathrm{~mm}$ で, 平行部を除いて電 着塗装により絶縁した。

\section{2 加工硬化を模擬する予ひずみ}

鉄筋破断はスターラップや主鉄筋の曲げ部位に集中し ている。そのため施工時の曲げ加工による加工硬化が水 素脆化に及ぼす影響を考慮する必要がある。土木学会制 定のコンクリート標準示方書 ${ }^{11)} に$ は鉄筋曲げ加工部の最 小曲げ半径が示されている. 鉄筋直径を $d$, 曲げ半径を $r$ として SD345 の曲げ加工部の最大ひずみ量を計算する と，それぞれの屈曲部位内側の最大ひずみ量は，屈曲鉄 筋の $r=5 d$ では $9.1 \%$, 軸方向鉄筋フック部の $r=2.5 d$ で

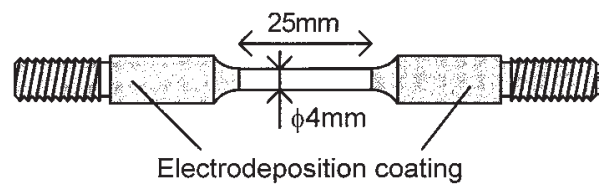

Fig. 1 Shape of specimen
は $16.7 \%$ ，スターラップ部位の $r=2.0 d$ では $20.2 \%$ とな る、同等の塑性ひずみを引張試験片に与えるため，空気 中で $4.0 \times 10^{-5} \mathrm{~s}^{-1}$ のひずみ速度で変位 $4 \mathrm{~mm}$ まで変形後 に応力を開放し，13.6\%の予ひずみ（塑性伸び約 3.4〜3.5 $\mathrm{mm}$ ，破断伸びの約 $50 \%$ ）を与えた試料を作製した。 $13.6 \%$ 塑性ひずみは試料にネッキングが生じない限界 量である。予ひずみにより試料の硬度は $H_{\mathrm{V}}=180 \sim 190$ から $H_{\mathrm{V}}=240$ に増加した。この硬化量は実使用品の屈曲 部内側に近い值である ${ }^{8)}$ 。 また予ひずみによって標点間 距離が $28.5 \mathrm{~mm}$ に増加したため, これを新たな標点間距 離としてひずみ量を計算した。予ひずみを与えた後，平 行部を＃1000 のエメリー紙で乾式研磨し蒸留水で洗浄し てから試験に用いた。

\section{3 溶液の決定}

コンクリート内部の鉄筋はコンクリート中に存在する 細孔溶液と接している. 細孔溶液をセメントの主成分で ある $\mathrm{Ca}(\mathrm{OH})_{2}$ 溶液と考えれば12), $\mathrm{Ca}(\mathrm{OH})_{2}$ の溶解度は 比較的小さくその飽和溶液の $\mathrm{pH}$ はおよそ 12.5 である. アルカリ骨材反応は $\mathrm{Na}^{+}$や $\mathrm{K}^{+}$が存在する $\mathrm{pH}=13 \sim 13.5$ のさらに高アルカリ環境で生じることから, $\mathrm{Ca}(\mathrm{OH})_{2}$ 飽 和溶液ではアルカリ性が不十分である可能性がある。し かしながら，実験結果で述べるように $0.5 \mathrm{M} \mathrm{NaCl}$ を含む 飽和 $\mathrm{Ca}(\mathrm{OH})_{2}$ 溶液と $1 \mathrm{M} \mathrm{NaOH}$ 溶液では, 鋼材の破断 挙動に明確な差異は認められなかった。このことから実 験溶液は $1 \mathrm{M} \mathrm{NaOH}$ と $0.5 \mathrm{M} \mathrm{NaCl}$ の混合溶液とし, 高 純度 $\mathrm{N}_{2}$ ガスで十分に脱気した後，試験に用いた。

\section{4 試 験 条 件}

引張試験は低ひずみ速度引張試験（Slow Strain Rate Test, SSRT）装置を用い，参照電極に飽和 $\mathrm{KCl} / \mathrm{AgCl} / \mathrm{Ag}$ 電極 (Silver Silver-chloride Electrode, SSE), 補助電極に 白金線を用いた。電解セル内を $\mathrm{N}_{2}$ で十分に脱気してか ら溶液を注入した。試験中は常に $\mathrm{N}_{2}$ ガスで脱気を行い ながら試料を $5 \mu \mathrm{A} \mathrm{cm}^{-2} \sim 1 \mathrm{~mA} \mathrm{~cm}^{-2}$ の範囲の一定カソ ード電流密度で分極し，水素をチャージしながらひずみ 速度 $4 \times 10^{-7} \sim 4 \times 10^{-5} \mathrm{~s}^{-1}$ で引張試験を行い, 破断ひず み量に及ぼす電流密度とひずみ速度の関係を調べた。ひ ずみ量はクロスヘッド変位と予ひずみを加えた後の試験 片の標点間距離 $28.5 \mathrm{~mm}$ から求めたものである。詳細な 試験条件は結果と共に個別に示す。破断後，破面を SEM によって観察した。

\section{3. 結 果 と考 察}

\section{1 破断ひずみ量に与える溶液種の影響}

飽和 $\mathrm{Ca}(\mathrm{OH})_{2}$ と $1 \mathrm{M} \mathrm{NaOH}$ にそれぞれ $0.5 \mathrm{M} \mathrm{NaCl}$ を加 えた溶液を用いて，鋼材の破断ひずみ量に与える溶液種 の影響を調査した。試験条件は $13.6 \%$ の予ひずみを与え た試験片を用い, カソード電流密度 $i_{\mathrm{c}}=20 \mu \mathrm{A} \mathrm{cm}^{-2}$ で水 素チャージを行いながら，ひずみ速度 $\dot{\varepsilon}=2.0 \times 10^{-6} \mathrm{~s}^{-1}$ で 行った. Fig. 2 に得られた応力ーひずみ曲線を示す. $\mathrm{Ca}(\mathrm{OH})_{2}, \mathrm{NaOH}$ のいずれの溶液を用いても, 破断ひず み量は水素をチャージしていない空気中での破断ひずみ 量に対して大きく減少したものの，両者に大きな差は見 られなかった。また破断面の観察結果でもほぼ等しい断 


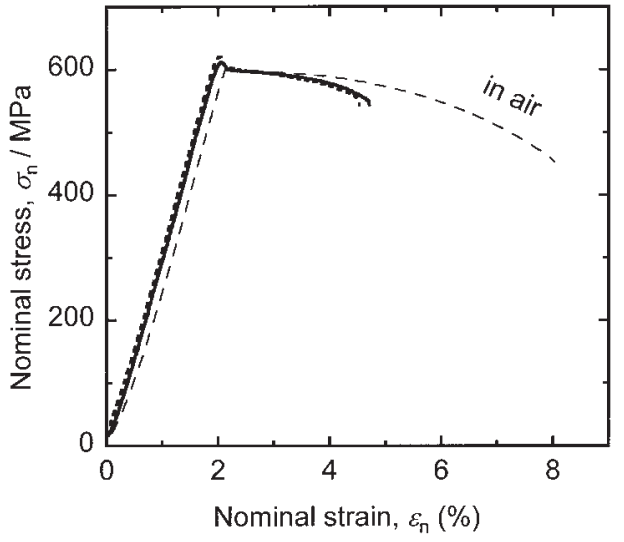

Fig. 2 Effect of electrolyte on fracture strain. $\dot{\varepsilon}=2.0 \times 10^{-6} \mathrm{~s}^{-1}$, $i_{\mathrm{c}}=20 \mu \mathrm{A} \mathrm{cm}^{-2}$.

: $1 \mathrm{M} \mathrm{NaOH}+0.5 \mathrm{M} \mathrm{NaCl}$

.....- : Saturated $\mathrm{Ca}(\mathrm{OH})_{2}+0.5 \mathrm{M} \mathrm{NaCl}$

面減少と脆性破面を示した. Lillard らは, 鋼材表面に存 在する $\mathrm{Ca}(\mathrm{OH})_{2}$ が水素の吸着効率を高め, 同一 $\mathrm{pH}$ では $\mathrm{NaOH}$ よりも水素透過電流が大きくなると報告している が13),14)，本実験の条件では明確な差異は認められなかっ た。

\section{2 ひずみ速度とカソード電流密度が破断ひずみ量 に及ぼす影響}

鋼材に水素チャージしながら引張試験を行うと, Fig. 2 のように破断ひずみ量の減少が見られる. 空気中での破 断ひずみ量に対する各条件での破断ひずみ量の変化を評 価した。同一カソード電流密度では，ひずみ速度の上昇 に伴い破断ひずみ量が空気中での值に近づいた。また同 一のひずみ速度ではカソード電流密度の増加とともに破 断ひずみ量は減少した. Fig. 3 は破断ひずみ量をひずみ 速度と電流密度に対してプロットしたもので, 図中の数 值は空気中での破断ひずみ量を $100 \%$ としたときのそれ ぞれの条件での破断ひずみ量を表している．破断ひずみ 量が空気中の $80 \%$ 以下の場合を水素脆化であるとして領 域を分けると，図中に示す左下がりの直線になり直線左 側の領域が脆化領域となる. Fig. 3 から，ひずみ速度が

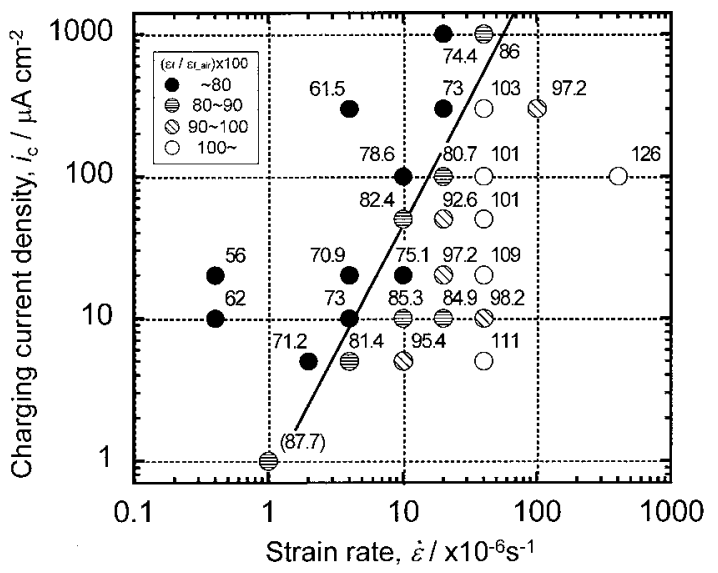

Fig. 3 Effects of charging current density and strain rate on fracture strain. Values in the figure indicate the ratio of fracture strain under hydrogen charging normalized by that in air.

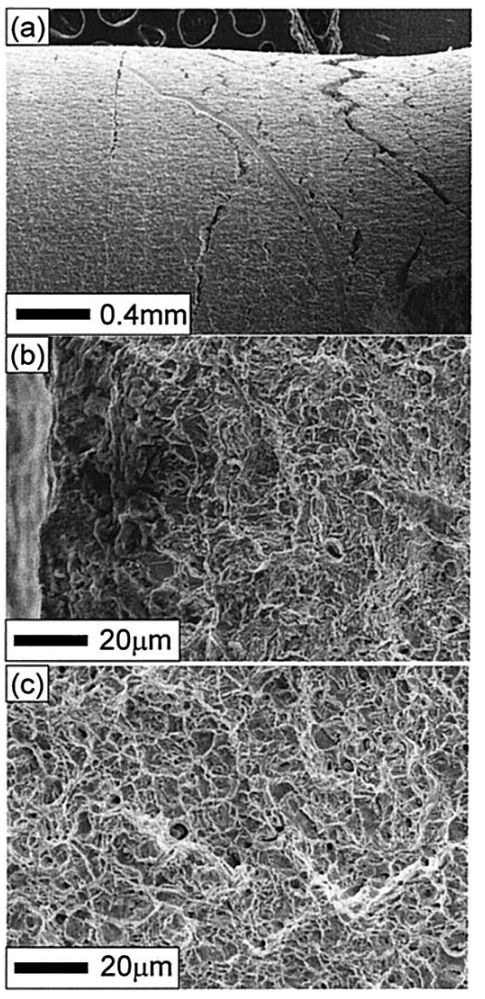

Fig. 4 SEM images of fracture specimen. $\dot{\varepsilon}=4.0 \times 10^{-6} \mathrm{~s}^{-1}, i_{\mathrm{c}}=$ $20 \mu \mathrm{A} \mathrm{cm}^{-2}$. (a) Lateral face (micro crack), (b) Outer edge (quasi-cleavage), (c) Center (dimple).

遅くなるとわずかな水素発生速度でも鉄筋が脆化するこ とがわかる．鉄筋破断事例では，鉄筋に顕著な腐食は見 られず，腐食反応に伴う水素発生速度は非常に小さいと 考えられるが，ASRによるコンクリート膨張速度も非常 に遅い。これらのことから，実環境における鉄筋破断に 水素脆化が関与している可能性が示唆される.

ひずみ速度 $\dot{\varepsilon}=4.0 \times 10^{-6} \mathrm{~s}^{-1}$, 電流密度 $i_{\mathrm{c}}=20 \mu \mathrm{A} \mathrm{cm}^{-2}$ で試験を行った場合に得られた破断した試験片の SEM 観察結果を Fig. 4 に示す. 破断部近傍の側面には引張軸 に対して垂直方向のクラックが多数観察された（Fig. 4 (a)). 破断面外縁部には水素脆化による擬へき開破面 が見られるが (Fig. 4(b)), 中央部は延性破壊でみられる ディンプルが占めている (Fig. 4(c))。 しかしながら脆性 破面と延性破面の境界は不明瞭であり，両者を明確に区 別することが困難で破断面における脆性破面率を求める ことは出来なかった. 破面の観察結果より, 鋼材表面か ら侵入した水素により脆化した外縁部にクラックが発生 し，進展することで破断に至ったと考えられる。つまり 鋼材全面が脆化していなくても外周部が水素により脆化 するだけで破断ひずみ量が減少することが示された。

\section{3 水素侵入時の弾性・塑性変形の影響}

水素脆化は, 鋼中の空孔, 転位などの可逆トラップサ イトに水素がトラップされることで生じると考えられて いる. 鋼材の変形過程は弾性変形と塑性変形に分けるこ とが出来るが，トラップサイトの振舞いは 2 つの変形過 程で大きく異なる。弾性変形は格子間距離の変化である が, 塑性変形領域では転位の運動や増殖が起こり, 空孔 量も増加する． 3.2 節での予ひずみ試験片は，いったん 


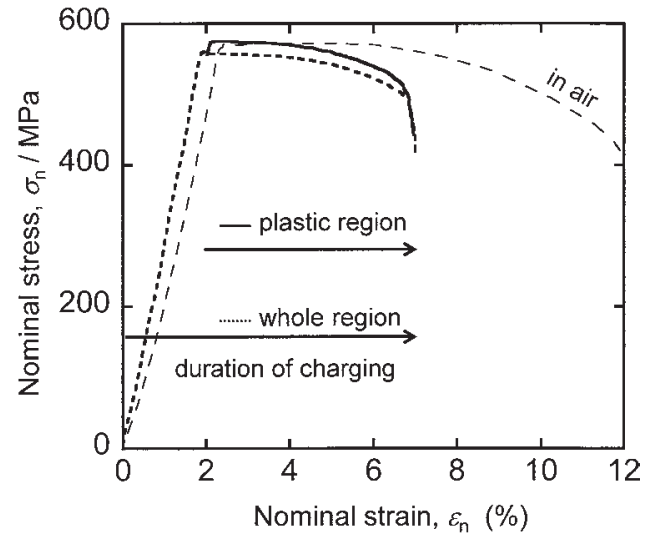

Fig. 5 Stress-strain curves of the steels with hydrogen charging in different deformation regions, $\dot{\varepsilon}=4.0 \times 10^{-6} \mathrm{~s}^{-1}, i_{\mathrm{c}}=20$ $\mu \mathrm{A} \mathrm{cm}^{-2}$.

----- : Charged during whole region

: Charged during plastic deformation region

除荷してから引張試験を行っており, 最大応力 $\left(\sigma_{\max }\right)$ ま では弾性変形，それ以降破断までは塑性変形していると みなせる。

トラップサイトの振舞いが水素脆化に及ぼす影響を調 べるため, 予ひずみ導入後除荷せず $\sigma_{\max }$ からカソード分 極を行い塑性領域のみで水素を侵入させたものと，除荷 後弾性領域から水素を侵入させたものとを比較した。ひ ず久速度 $\dot{\varepsilon}=4.0 \times 10^{-6} \mathrm{~s}^{-1}$, 電流密度 $i_{\mathrm{c}}=20 \mu \mathrm{A} \mathrm{cm}^{-2}$ の条 件で得られた応力ーひずみ曲線を Fig. 5 に示す. 実線で示 した塑性領域のみで水素チャージを行った場合の破断ひ ずみ量は，点線で示す全領域でチャージした場合とほぼ 同じ值を示した。この傾向はひずみ速度を変えても見ら れた ${ }^{15)}$ 。この結果より, 鋼材の水素脆化には転位が運動 している過程で侵入する水素が最も有効に作用している といえる. 除荷後に試験した場合は弾性領域の分だけ水 素チャージ時間が長くなる.すなわち蓄積水素量が多く なる. Fig. 5 の場合 $\dot{\varepsilon}=4.0 \times 10^{-6} \mathrm{~s}^{-1}$ でありこの試験の水 素チャージ時間の差はおよそ $1.8 \mathrm{~h}$ である.さらに $\dot{\varepsilon}=$ $4.0 \times 10^{-7} \mathrm{~s}^{-1}$ の場合についても破断ひずみ量に差は認め られなかった。このひずみ速度では， $\sigma_{\max }$ に到達するま でに要する時間は抢よそ $17 \mathrm{~h}$ である. 鋼中の水素拡散倸 数を $D=1.0 \times 10^{-6} \mathrm{~cm}^{2} / \mathrm{s}^{16)}$ として計算すると, 直径 4 $\mathrm{mm}$ の円柱試験片中央部の水素濃度が表面近傍の濃度 $C_{0}$ に到達するのに要する時間は抄よそ $9 \mathrm{~h}$ となる17) ため, 均一に水素が侵入するのに必要な時間を大幅に超えてい る.しかしながら，破断ひずみ量に差がみられないこと から, 転位の運動がない弾性領域で侵入した水素は脆化 にほとんど寄与しないといえる。

\section{4 蓄積水素濃度の影響}

蓄積水素量が破断ひずみ量に及ぼす影響を調べるた め, $\sigma_{\max }$ でひずみを保持した状態で均一拡散に必要な 9 $\mathrm{h}$ を大幅に超える $40 \mathrm{~h}$ 水素を予備チャージした場合と, 3.3 節の塑性領域のみ水素チャージ $\left(\sigma_{\max }\right.$ 到達後直ちに水 素チャージを開始）したものを比較した， $\sigma_{\max }$ までのひ ずみ速度は $\dot{\varepsilon}=4.0 \times 10^{-6} \mathrm{~s}^{-1}$ で, 電流密度は予備チャー ジおよび変形中ともに $i_{\mathrm{c}}=20 \mu \mathrm{A} \mathrm{cm}^{-2}$ である。また $\sigma_{\max }$ 以降のひずみ速度は $\dot{\varepsilon}=4.0 \times 10^{-6} \mathrm{~s}^{-1}$ である。蓄積水素

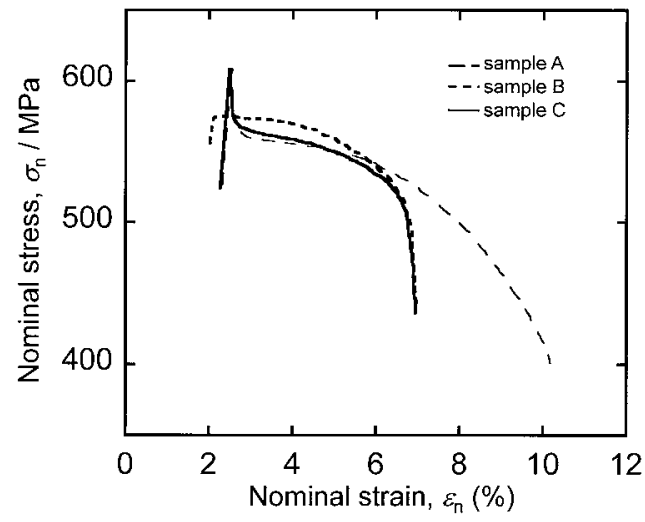

Fig. 6 Stress-strain curves of the steels on various charging conditions. Sample : holding strain at $\sigma_{\max }$ for $45 \mathrm{~h}$ in air then deformed without charge. $\mathrm{B}:$ Charged during plastic deformation region. $\mathrm{C}$ : holding strain at $\sigma_{\max }$ and charged for $40 \mathrm{~h}$ and then deformed while charging hydrogen. $\dot{\varepsilon}=4.0 \times 10^{-6} \mathrm{~s}^{-1}, i_{\mathrm{c}}=20 \mu \mathrm{A} \mathrm{cm}^{-2}$.

量を変化させた場合の応力-ひずみ曲線を Fig. 6 に示す. 実線で示した試験片 A は予ひずみ後除荷せずに水素チャ ージを $40 \mathrm{~h}$ 行った後に水素チャージを継続しながら引張 試験を再開, 点線で示した試験片 B は予ひずみ後除荷せ ずに水素チャージを開始し直ちに引張試験を再開したも のである. 同図には空気中で $45 \mathrm{~h} \sigma_{\max }$ に保持した後に試 験を再開したものも破線で合わせて示す.

図から明らかなように, 予備チャージによる脆化への 影響は見られなかった。同図での上部降伏点は, 空気中 で保持した試験片でも見られることから，炭素の拡散に よるひずみ時効の効果と考えられ, 予備チャージの水素 による転位固着効果は小さいと考元られる． $\sigma_{\text {max }}$ で保持 して $i_{\mathrm{c}}=20 \mu \mathrm{A} \mathrm{cm}^{-2}, 40 \mathrm{~h}$ の予備チャージ後, $\dot{\varepsilon}=4.0 \times$ $10^{-6} \mathrm{~s}^{-1}$ で引張試験を行った場合の破断部位の SEM 像を Fig. 7 に示す. 外縁部には擬へき開破面が存在したが (Fig. $7(\mathrm{a})$ ), 中央部まで水素で十分に飽和しているにも かかわらず表面から $600 \mu \mathrm{m}$ 付近からディンプルが現れ, 中央部に延性破壞破面がみられる傾向は変わらなかった (Fig. 7 (b))。以上の結果は， $\sigma_{\max }$ に保持した状態は弾性 変形領域と同様に転位がほとんど運動していないことと 対応しており，そのような状態で侵入した水素は脆化に 寄与しないことを示している，言い換えると，転位が運 動している状態で侵入した水素が脆化に寄与するといえ る.

\section{5 予ひずみ量の影響}

一般に鋼材の引張試験では，上部降伏点が現れるまで は弾性変形が進行し，下部降伏点付近の応力で塑性変形 が進行し, 加工硬化により再び応力が上昇し始める. 塑 性変形領域では転位の運動によって変形が進行する。 そ こで, 転位の運動と侵入する水素との関係を調べるため, 予ひずみ量を元の標点間隔 $25 \mathrm{~mm}$ に対して $3 \%, 6 \%$, 9\%とし, その後の引張試験における塑性変形領域を変 化させて, 塑性領域のみ水素チャージを行った. 変形速 度は $6.0 \times 10^{-3} \mathrm{~mm} \mathrm{~s}^{-1}$ (13.6\%の予ひずみ試験片で $\dot{\varepsilon}=$ $4.0 \times 10^{-6} \mathrm{~s}^{-1}$ に相当), 電流密度は $i_{\mathrm{c}}=20 \mu \mathrm{A} \mathrm{cm}^{-2}$ である. Fig. 8 にそれぞれの予ひずみを与えた場合の応力-伸び曲 線を示す。予ひずみ量が $13.6 \%$ の結果は 3.3 節で得られ 

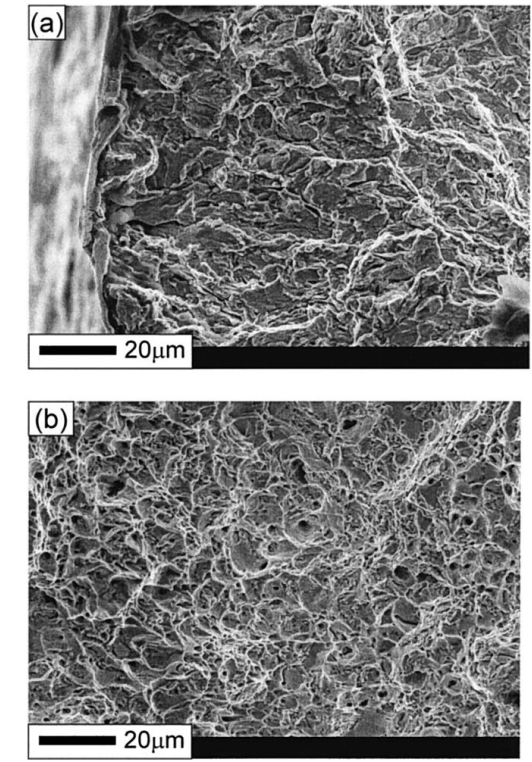

Fig. 7 SEM images of fracture surface, holding strain at $\sigma_{\max }$ and charged for $40 \mathrm{~h}$ and then deformed charging hydrogen. $\dot{\varepsilon}=4.0 \times 10^{-6} \mathrm{~s}^{-1}, i_{\mathrm{c}}=20 \mu \mathrm{A} \mathrm{cm}^{-2}$. (a) Outer edge (quasicleavage), (b) Center (dimple).

たものである．水素侵入開始点や予ひずみ量の違いによ る曲線形状に差は見られず, 加工硬化の程度や破断伸び はほぼ一致していることがわかる。破断までに試料に印 加された全カソード電気量は $3 \%$ の予ひずみ試験片と 13.6\%の予ひずみ試験片では数倍以上異なるが，破断伸 びに影響していない。このことは, 前節の結果と合わせ て, 最大応力 $\sigma_{\text {max }}$ よりも前に侵入した水素は脆化にほと んど寄与しないことを示しており, 動的ひずみ下での脆 化現象には水素の拡散だけではなく転位の挙動も大きく 関与することを示唆している.

\section{6 動的ひずみ下での破断機構}

本研究における変数はひずみ速度 $\dot{\varepsilon}$ とカソード電流密 度 $i_{\mathrm{c}}$ である.巨視的ひずみ $\varepsilon$ は転位密度 $\rho$, バーガース ベクトル $\boldsymbol{b}$, 転位一本当りの移動量 $x$ を用いて, 公称ひ ずみ量を

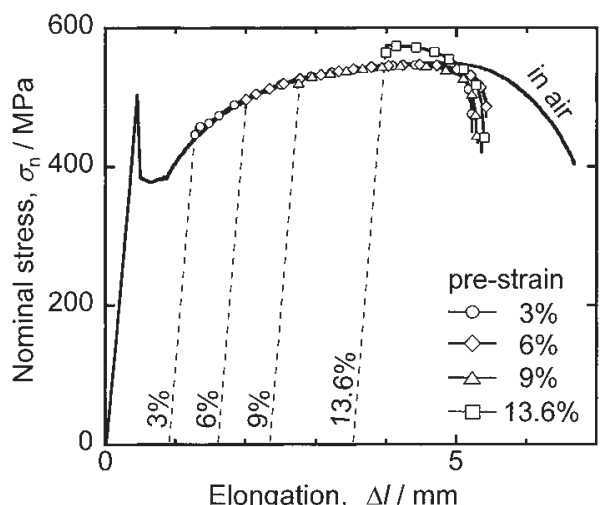

Fig. 8 Stress-elongation curves of steels pre-strained 3\% to $13.6 \%$. Crosshead speed is $6.0 \times 10^{-3} \mathrm{~mm} \mathrm{~s}^{-1}, i_{\mathrm{c}}=$ $20 \mu \mathrm{A} \mathrm{cm}^{-2}$ Pre-strain ; 3\% $\left.\bigcirc\right), 6 \%(\diamond), 9 \%(\triangle)$, and $13.6 \%(\square)$. $\varepsilon=\rho \boldsymbol{b} x$

と表すことができる。両辺を時間 $t$ で微分すれば巨視的 ひずみ速度 $\dot{\varepsilon}$ が得られ，

$$
\dot{\varepsilon}=\dot{\rho} \boldsymbol{b} x+\rho \boldsymbol{b} v
$$

となる. $\dot{\rho}$ は単位時間当たりの転位密度の増殖量, すな わち転位の増殖速度であり, $v$ は転位の運動速度である。 炭素鋼のような bcc 金属のらせん転位に対するパイエル ス応力は大きく, 高いパイエルスポテンシャルの山を越 えながら運動するので転位の移動距離 $x$ は小さく, 転位 の運動速度 $v$ は本質的に小さいものになる. 一方, bcc 金属である炭素鋼は積層欠陥エネルギーが大きく，交差 すべりによる転位源の発生と活動も容易に起こり, 転位 密度 $\rho$ は速やかに増加する. すなわち転位密度の増加速 度 $\dot{\rho}$ が大きくなる．このような右辺第二項が小さくなる 条件ではひずみ速度 $\dot{\varepsilon}$ 変化させることは転位密度 $\rho$ を 変化させることになる. 一方, カソード電流密度 $i_{\mathrm{c}}$ は単 位時間当たりに発生する水素量と対応しており, 鋼中へ の水素侵入速度に対応する. 材料の変形に関係する転位 密度 $\rho$ と, 材料の変形を阻害する水素侵入速度 $i_{\mathrm{c}}$ の大小 関係によって破断ひずみ量および断面減少量が変化，す なわち脆化率が変わると考えられる。

最大応力 $\left(\sigma_{\max }\right)$ より前の塑性変形領域で侵入した水素 に対して，南雲ら ${ }^{18)}$ は IF 鋼に様々なひずみを導入した 後に $\mathrm{NH}_{4} \mathrm{SCN}$ を含む $\mathrm{NaCl}$ 溶液中で $0.5 \mathrm{~mA} \mathrm{~cm}{ }^{-2}$ でカソ ード分極し，その後水素分析を行い鋼中に蓄積した水素 量を調べており, その結果ひずみ量の増加と共に蓄積水 素量も急激に増加すると報告している。一方，ひずみを 導入した後水素チャージを行う前に $373 \sim 873 \mathrm{~K}$ で 30 min 熱処理を行ってから同様の実験を行うと熱処理温度 の上昇に伴って放出水素量が減少することから, 蓄積水 素量の増加は空孔などの点欠陥の増加に起因すると述べ ている. $\sigma_{\max }$ より前の塑性変形領域では, 試験片の平行 部全体が均一に変形している. 平行部長さ $L_{0}$ に対して伸 び $\Delta l$ は小さいので, 真ひずみ量 $\varepsilon_{\mathrm{t}}$ と公称ひずみ量 $\varepsilon_{\mathrm{n}}$ の 差は小さく $\varepsilon_{\mathrm{t}} \doteqdot \varepsilon_{\mathrm{n}}=\Delta l / L_{0}$ と表され, 変形に伴う転位密 度の増加量もそれほど大きくない。 また, 水素と原子空 孔間の結合エネルギー $E_{\mathrm{H}-\mathrm{V}}=40 \sim 60 \mathrm{~kJ} / \mathrm{mol}^{19), 20)}$ は転位 と水素間の $E_{\mathrm{H}-\mathrm{D}}=20 \sim 35 \mathrm{~kJ} / \mathrm{mol}^{21)}$, 22) よりも大きく, 拡 散性水素の中でも比較的強い結合エネルギーを持つ.こ れらのことから， $\sigma_{\max }$ より前に侵入した水素は主に空孔 にトラップされていると考えられる. $3.3 \sim 3.5$ 節で $\sigma_{\text {max }}$ より前に侵入した水素による効果が現れないのは, カソ ード分極により外部から侵入した水素は主に原子空孔に トラップされ, それらの水素は変形が進行しても空孔に とどまり続けるためであると考えられる.

SSRT 試験は非常に小さなひずみ速度であり, 転位密 度 $\rho$ は $\sigma_{\max }$ より前では大きく変化しない. 一方, $\sigma_{\max }$ を 越えると変形する部位が局在化し, 絞り変形が生じる。 絞り変形の進行に伴う変形の局在化により絞り変形部位 の転位密度は急激に増加する．この急激に増加した転位 と水素の相互作用によって脆化が生じると考えられる。 転位と水素の相互作用による水素脆化の機構としては, 水素による転位の固着説と水素助長局所塑性変形理論 (Hydrogen-Enhanced Localized Plasticity, HELP) ${ }^{23)}$ があ る. 前者は, 転位にトラップされた水素が転位の運動を 阻害し変形能が低下して破断に至る機構である。 3.3 節 
での蓄積水素量を増加させた場合に降伏応力に変化がみ られなかった結果が示すように，炭素による転位のコッ トレル固着能の影響が大きく，この効果を確認すること はできなかった。一方，後者の機構は，水素が転位間の 相互作用を弱めることで堆積する転位同士の間隔が短く なり転位同士が合体して微細なき裂が生成 ${ }^{24)}$, 水素環境 下でき裂先端からの転位の発生が容易になりき裂進展が 活性化 ${ }^{25)}$ するというものである.しかしながら水素によ る変形能の低下は応力-ひずみ曲線からは確認すること が出来なかったため, 本研究では脆化がどちらの機構に より生じたものかを明らかにすることは出来ないが，水 素と転位の相互作用によって発生するものであるから， $\sigma_{\max }$ 以降の塑性変形によって急激に増加した転位にトラ ップされる水素の量が重要であると考えられる.

以上の実験結果および考察から，3.2 節において，ひ ずみ速度 $\dot{\varepsilon}$ が小さくなると微少な $i_{\mathrm{c}}$ でも脆化する現象は, 以下のように説明される。ひずみ速度㐫が大きい場合は, 単位時間当たりに発生する転位量 $\dot{\rho}$ が増加し転位と相互 作用を起こすのに必要な水素量が増加する。すなわち大 きな水素侵入速度を必要とする. カソード電流密度 $i_{\mathrm{c}}$ を 大きくすると, 転位への水素の供給が間に合うことにな り, 脆化が進行する。一方, $\dot{\varepsilon}$ が小さい場合は, 微少な $i_{\mathrm{c}}$ すなわち水素侵入速度が小さくても転位の増加速度に比 べて脆化に十分な水素供給量となる。 その結果, 前述の 機構のいずれかによって脆化が生じ, Fig. 4(a)で観察さ れたようなマイクロクラックが発生し, それらを起点と して破断が起こると考えられる，以上の検討では，転位 密度の増加量は塑性ひずみ量にのみ依存するとしている が，今回の試験では平滑丸棒試験片を使用したため, 絞 り変形時の引張試験片の絞り部位の形状（断面減少率, 絞りの曲率) がカソード電流密度やひずみ速度によって 異なる。この場合, 条件ごとに局所的な転位密度の増加 量に違いが見られる可能性がある. 変形が局在化した絞 り変形後に脆化に対して水素の影響が顕著に見られるこ とから, 切欠き試験片のような変形部位を限定した試験 を用いてさらに検討する必要がある。

ASR を起こしたコンクリート構造物内の鉄筋破断事例 において，施工時に大きな曲げ加工を受けた鉄筋が ASR の反応に伴って発生する非常に大きいコンクリート膨張 圧によって非常にゆっくりとした速度で変形する際，腐 食反応に伴う水素発生速度が小さくても水素脆化によっ て破断が起こりうることが, 本研究の結果から示され た。

\section{4. 結}

ASR コンクリートでの鉄筋破断事例に対して, 高アル カリ塩化物環境下でカソード分極によって水素をチャー ジしながら低ひずみ速度引張試験（SSRT）を行い, 動的 ひずみ下での炭素鋼の脆化挙動について検討し, 結果以 下のことがわかった。

1）ひずみ速度が遅くなると小さいカソード電流密度 でも脆化が認められた。これは実際の ASR コンクリート のような非常に遅いひずみ速度の場合，大きな曲げ変形 を受けた鉄筋などで腐食反応に伴う極めてわずかな水素 発生量でも脆化が起こる可能性を示唆する.
2）水素をチャージしながら引張試験を行い，破断ひ ずみ量が減少した試験片の破断面を SEM により観察し た結果，外縁部には擬へき開破面が見られ，中央部は延 性破面で占められることが分かった．また，鋼中の水素 濃度の均一あるいは不均一に関係なく破断ひずみ量が減 少し，脆性破面が観察された。

3）動的ひずみ下では, 最大応力以降の絞り変形が生 じている状態で侵入する水素が脆化に最も関与する。こ れは絞り変形における変形の局在化によって，局所的に 転位密度が急激に上昇することが要因であると考えられ る.

\section{参 考 文 献}

1） H. Tamura, “Arukari kotuzai hannou（アルカリ骨材反 応)”, Gihodo-shuppan, p.42 (1986).

2) A. Sato, H. Suzuki, N. Takagi and T. Kojima, Japan Society of Civil Engineering, Kansai Chapter Proc. of Annual Conf. of Civil Engineers. V-13-1 (2004).

3) K. Torii, O. Iketomi, Y. Kubo and M. Kawamura, Proc. Japan Concrete Institute, 23 [2] 595 (2001).

4) M. Kumazawa, T. Nishioka, T. Iwasaki and K. Sasaki, Proc. 59th Annu. Conf. Japan Society of Civil Engineering, 59, $\mathrm{V}-018,35$ (2004).

5) Concrete library 124 "State-of-the-Art Report on the Countermeasures for the Damage Due to Alkali-Silica Reaction", Japan Society of Civil Engineering, (2005) .

6) K. Torii, T. Tarui, T. Ooshiro and Hirano, Proc. Japan Concrete Institute, 28, 783 (2006).

7) K. Kuzume, T. Minami and S. Matsumoto, Proceedings of the Concrete Structure Scenarios, Vol.3, Japan Society of Materials Science, 7 (2003).

8) K. Sasaki, T. Nishioka, T. Minami and T. Miyagawa, Proceedings of the Concrete Structure Scenarios, Vol.4, Japan Society of Materials Science, 82 (2004).

9）S. Matsuyama, “Okurehakai（遅れ破壊）”, The Nikkan Kogyo Shimbun, Ltd., 70 (1989).

10) M. Kobayashi, T. Tsuru, A. Tanimitsu and A. Nishikata, Proc. JSCE Materials and Environments 2005, p.298, JSCE (2005).

11) JSCE Guidelines for Concrete No.3 -Standard Specifications for Concrete Structures -2007 "Structural Performance Verification"-, Japan Society of Civil Engineering, 195 (2007)

12) H. Kagimoto, M. Sato and M. Kawamura, Journal of Materials, Concrete Structures and Pavements $(\mathrm{V}),[641] \mathrm{V}$ 46, 241 (2000).

13) R. S. Lillard and J. R. Scully, Corrosion, 52, 125 (1996).

14) R. S. Lillard, D. G. Enos, and J. R. Scully, Corrosion, 56, 1119 (2000)

15) M. Kobayashi, A. Nishikata and T. Tsuru, Proc. JSCE Materials and Environments 2006, p.268, JSCE (2006).

16) Y. Huang, A. Nakajima, A. Nishikata and T. Tsuru, ISIJ Int. , 43, 573 (2003).

17) J. Crank, "The mathematics of diffusion 2nd ed.", Oxford University Press, 73 (1979).

18) M. Nagumo, K. Takai and N. Okuda, Journal of Alloy and Compounds, 293-295, 310 (1999).

19) S. M. Myers, S. T. Picraux and R. E. Stoltz, J. Appl, Phys., $50,5710(1979)$

20) Y. Tateyama and T. Ohno, ISIJ Int., 43, 573 (2003).

21) C. M. Shurges and A. P. Miodownik, Acta. Metall., 17, 1197 (1969).

22) Y. Ogino, M. Nagahama and T. Yamada, J. Japan Inst. Metals, 52 [4] 395 (1988).

23) M. Nagumo, Zairyo-to-Kankyo, 56, 343 (2007).

24) P. Sofronis and H. K. Birnbaum, J. Mech. Phys. Solids, 43, 49 (1995)

25） T. Tabata and H. K. Birnbaum, Scr. Metall., 18, 231 (1984).

(Manuscript received October 25, 2009; in final form January 15, 2010) 
要 旨

低ひずみ速度引張試験によってアルカリ骨材反応を生じたコンクリート模擬環境での炭素鋼の水素脆化 を調へ，破断ひずみ量に及ぼすひずみ速度と水素発生電流の影響を検討した。その結果，十分小さなひず み速度においてごくわずかな水素発生電流でも破断ひずみ量の低下が起こることが分かった。破断面には 水素の影響と思われる擬へき開破面が観察された。動的ひずみ下では，最大応力以降の絞り変形が生じて いる状態で侵入する水素が脆化に最も関与することが分かった。一方で, 弾性変形領域や最大応力以前の 塑性変形領域で鋼中に侵入した水素は脆化にほとんど影響しないことが確認された。

キーワードアルカリ骨材反応，鉄筋破断，水素脆化，低ひずみ速度引張試験 (SSRT), 塑性変形, 絞り変形 